\title{
Factors That Influence The Intention of The Millennial Community to do Waqf With a Modification of Theory Planned Behavior Approach
}

\author{
Abdullah Achmad Zawawi ${ }^{1}$, Tatik Mariyanti ${ }^{2}$, Siti Nurindah Sari ${ }^{3}$ \\ ${ }^{1,2}$ IEF Trisakti University, Jl. Kyai Tapa No.1, RT.6/RW.16, Grogol, \\ Kec. Grogol petamburan, Kota Jakarta Barat, Daerah Khusus Ibukota Jakarta 11440. \\ ${ }^{3}$ University of Raharja Modern, Jl. Jenderal Sudirman No.40, Cikokol, Kec. Tangerang, Kota \\ Tangerang, Banten 15117 \\ e-mail: abdullahahmadzawawi@gmail.com ${ }^{1}$, tatik m2002@yahoo.com ${ }^{2}$, \\ siti.nurindah@raharja.info $^{3}$
}

\section{Article Info}

\section{Article history:}

Received 14-12-2021

Revised 4-1-2022

Accepted 1-1-2023

\section{Keywords:}

knowledge

attitude

religious commitment

subjective norm

use of technology ICT

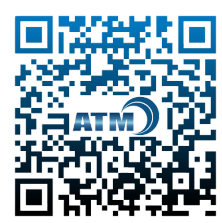

\begin{abstract}
PT)
This research aims to analyze the influence of variables knowledge, attitudes, religious commitment, subjective norm, and the use of ICT Technology significantly influence behavior through the intention of the millennial generation in waqf in Jabodetabek. The methodology used in this study is the Structural Equation Model with the variables of knowledge, attitudes, religious commitment, subjective norms, and ICT technology as independent variables; intention as moderating variable, and waqf behavior as the dependent variable. The primary data of this study was obtained through a questionnaire survey to 290 respondents obtained through purposive random sampling from the millennial generation aged 21-40 years who live in Greater Jakarta. Then the data was analyzed using SPSS and AMOS software. Based on the results of this study, it was learned that the variable of knowledge does not affect the behavior of waqf through the intention of the millennial generation. In contrast, the variables of attitude, commitment, subjective norms, and the use of ICT technology had a positive and significant effect on waqf behavior through the intention of the millennial generation. This shows that the millennial generation, although their knowledge does not affect behavior, attitudes, commitment, subjective norms, and the use of ICT technology, have a positive and significant effect on waqf behavior results of this study indicate that the variables attitudes, religious commitment, subjective norm, and the use of ICT Technology significantly influence behavior through the intention of the millennial generation in waqf in Jabodetabek. At the same time, knowledge does not affect that behavior. This study implies that measuring consumer behavior should be equipped with additional indicators, namely intention, to analyze the behavior based on external factors and spiritual and social aspects.
\end{abstract}

This is an open access article under the CC BY 4.0 license.

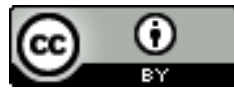

\section{Corresponding Author:}

Siti Nurindah Sari

University of Raharja, Tangerang, Indonesia

Email: siti.nurindah@raharia.info 


\section{INTRODUCTION}

\subsection{Background}

Waqf is an institution built and developed by Islamic culture. This institution has a vital role in the Muslim community in supporting their lives; therefore, it has become imperative in the history of Islam and the Muslims[1].

Data from the Indonesian Waqf Agency (BWI), the potential for waqf in Indonesia is currently quite large, reaching 2000 trillion with an area of 420 thousand hectares of waqf land and cash waqf reaching Rp. 188 Trillion. Meanwhile, the Ministry of Religion data explains that the amount of waqf land reaches 161,579 hectares[2]. The area of waqf assets spread over 366,595 locations is the most significant number globally. If this potential can be achieved, it can be used as a turning point for the people's economic revival.

Someone who wants to do waqf is based on several factors, including knowledge. States that knowledge only affects indirectly. Meanwhile states that knowledge has a significant effect on wakif decisions[3]. Currently, the knowledge of the Muslim community is still low, so an introduction is needed to realize the importance of waqf and its institutions. The results of the waqf literacy index survey from the Indonesian Waqf Agency in 2020[4] stated that the national waqf literacy index (ILW) score as a whole got a score of 50.48 and was in a low category.

One of the previous studies regarding people's intentions to waqf is a study conducted by (Huda, Barata, \& Rahadiana, Potential Endowments (Waqf) Development Strategy Based on Waqif Household and Economic Infrastructure Index of Province in Indonesia, 2014) to calculate the potential for waqf receipts in Indonesia for each province[5]. The results of this study indicate a mapping of the potential for waqf receipts in Indonesia.

Based on the phenomenon of the gap and research gap that have been described previously, the researchers are interested in examining the relationship between knowledge, attitudes, religious commitment, subjective norms, and the use of ICT technology on the behavior of millennial people in waqf with the TBP approach to identify the factors that motivate waqif in their intentions[6] for waqf. By knowing the factors that influence the intention of waqf to do waqf, a solution will be found in the problem of potential waqf that has not been realized optimally[7].

\subsection{Problem Identification and Problem Formulation \\ 1.2.2 Identification of Problems}

Indonesia has enormous potential in developing waqf because most of the population is Muslim. Through Law no. 41 of 2004 concerning waqf, the government provides opportunities for the development of waqf in Indonesia[8]. However, there has not been significant development of waqf, even lagging by several other Islamic countries. This fact is evidenced by several studies on the phenomenon of waqf in the country. The potential for cash waqf [9], the potential for cash waqf can reach 157 trillion annually if the community is waqf with a voucher scheme of 100 thousand waqfs per month[10]. However, in reality, the realization of waqf collection is still relatively far from the existing potential, as data in the 2019 Dompet Dhuafa annual report shows that waqf collection only reached 23.4 billion per year BWI report accumulated waqf fund collection as of February 2021, reaching 831 billion[11]. In other words, that the current collection of waqf has not reached even $1 \%$ of the existing potential, the gap between the potential and the results of the collection of cash waqf is still very far from what is expected[12].

From these studies, waqf problems in Indonesia can be formulated as follows:

1. Some Muslim communities still have a common understanding of productive waqf, nazir, and wakif.

2. There is still low awareness of waqf as a form of alms.

3. Not optimal use of information and communication technology in waqf management.

4. The realization of waqf receipts has not been optimal compared to its potential.

5. The lack of involvement of millennials in waqf matters.

6. Waqf is still understood as consumptive waqf, not productive.

7. People do not understand the difference between swaps.

8. Waqf is mostly used for the construction of mosques and Islamic boarding schools.

In line with the background of this research, there are 6 (six) Research Questions (RQ) as follows:

1. How does knowledge influence behavior through millennial intentions to waqf?

2. How does attitude influence behavior through millennial intentions to waqf?

3. How does religious commitment affect behavior through millennial intentions to waqf?

4. How do subjective norms influence behavior through millennial intentions to waqf?

5. How does the use of technology affect behavior through millennial intentions to waqf?

6. How does intention affect behavior for waqf? 


\subsection{Research Purpose}

Based on the previous research questions, this study aims to analyze and prove empirically:

1. The influence of the knowledge factor on behavior through the intention of millennials to do waqf.

2. The influence of attitude factors on behavior through millennial intentions to do waqf.

3. The influence of the religious commitment factor on behavior through the millennial intention to do waqf.

4. The influence of subjective norm factors on behavior through millennial intentions to perform waqf.

5. The influence of technology influences behavior through millennial intentions to do waqf.

6. The influence of the Intention factor on millennial behavior to do waqf.

\subsection{Benefits of Research}

The theoretical benefit of this research is to contribute to literacy about measuring consumer behavior and the factors that influence it with the Theory of Planned Behavior approach by adding the variable of using ICT technology as a modification of the behavioral control variable component[13]. This theoretical approach can predict and understand motivational influences on behavior that are not under the control or will of the individual himself[14].

The benefit of the practice for the wider community is that the results of this research are expected to provide input or information for the government, waqf institutions, Islamic banking, Mazhar, and other stakeholders related to measurement and the factors that influence it. Thus all stakeholders (stakeholders) can give trust to waqf institutions[15], Islamic banks, Mazhar and also support the development of waqf so that it is expected to improve the economic welfare of the community[16].

\subsection{Significance of Writing}

This research aims to analyze the behavior of waqf with the Theory of Planned Behavior approach[17]. The difference between this research and previous research is that this research focuses on the behavior of millennial people in waqf. Previous research discusses public behavior in general[18]. In addition, this study also adds a variable that is different from previous research, namely the use of ICT technology as a modification of the behavioral control variable component [19].

\section{LITERATURE REVIEW}

\subsection{Tawhidi String Relation (TSR) Methodology}

Tawhidi String Relation (TSR) explains the oneness of God in the world system as complete, absolute, and perfect knowledge. The fundamental epistemology of the oneness of Allah comes from the Qur'an and in the real world is explained in the Sunnah of the prophet Muhammad[20].

The knowledge that comes from the Qur'an and in the implementation explained through the Sunnah will give birth to new knowledge through the process of tasbih and shura [21]. Tasbih means contemplating within oneself through remembrance and thought; the Suratic process is a process of study and deliberation to obtain Qur'anic knowledge derived from the Qur'an and Al- Hadith relating to human life and the universe world system[22]. In this system, there will be a strong interaction between humans, the Qur'an, the Sunnah, and knowledge that comes from other Sunnatullah[23]. Through interaction, integration emerges as a sign of a unified consensus among deliberation participants exploring God's knowledge. This integration, in turn, is followed by a creative evolutionary process to apply Allah's knowledge in human life in this world, which will benefit the 'ummah' both in this world and in the hereafter (al-Falah) / social wellbeing. This concept in TSR is called the IIE process, namely, Interaction, Integration, and Creative Evolution[24]. The knowledge derivation process through IIE can be seen in Figure 1.

$\{(\Omega, \mathrm{S}) \ni \theta\} \rightarrow\{(\theta, \mathbf{X}(\theta)\} \rightarrow\{\mathrm{f}(\theta, \mathbf{X}(\theta)\} \rightarrow$ Evaluate $\mathrm{W}(\theta, \mathbf{X}(\theta)) \rightarrow$ Continuity


Subject to Circular
Causation (Qur'anic
pairing)
$\mathrm{X}_{\mathrm{i}}(\theta)=$
$\mathrm{f}_{\mathrm{i}}\left(\mathrm{X}_{\mathrm{j}}(\theta)\right)$, where
$\mathrm{i}, \mathrm{j}=1,2, \ldots, \mathrm{n}$
This is end of process 1 \&
subsequent process of IIE learning is done
by recalling $(\Omega, \mathrm{S})$ as the methodological
foundation of this methodology

Figure 1. Knowledge Derivation Process Based on the Concept of Tawhidi String Relation 
In Figure 1, it can be seen that the symbol $\Omega$ indicates knowledge sourced from the Al- Quran, which is explained through the Sunnah (S), Based on the Qur'an and Sunnah $(\Omega)$, with the tasbih and sura processes, consciousness is generated in the form of knowledge and charity. is induced into social scientific variables in the world-system become, so $\mathrm{Xi}$ is a vector of (X1. X2X2...Xn) which is an endogenous variable. The IIE process occurs in $(\mathrm{X})$ to realize wellbeing $(\mathrm{W}(\theta, \mathrm{X}(\theta))$, symbolizes the evaluation of the wellbeing function which is formed from the complementarity between the variables.

So in the TSR (Tawhidi String Relation) model proposed[25], all subsystems in a system are related to each other with a circular causation pattern in realizing wellbeing. The TSR model has three premises: first, complexity and endogeneity, which means that a variable cannot stand alone and influence one another, Participatory Among People, that in realizing a common goal, namely wellbeing, every agent or person must participate in contributing. Third, Interactive, Integrative and Evolutionary (IIE) means that each variable will interact, integrate, and move dynamically (learning process) [26].

\subsection{Tabarru' Contract}

The data analysis method used in this research is the multiple linear regression method. Multiple linear regression analysis provides facilities to objectively assess the degree and character of the relationship between the independent and dependent variables. The influence between variables in this study can be known using the SPSS (Statistical Package for the Social Science) application. The form of the equation of the path is as follows:

Waqf is one of the tabarru' contracts. Tabarru contract (gratuitous contract) is all kinds of agreements concerning not-for-profit transactions (non-profit transactions) [27]. This transaction is not essentially a business transaction for commercial gain. The tabarru' contract is carried out to help in doing good (tabarru' comes from the word birr in Arabic, which means goodness). In the tabarru contract, the party who does the good is not entitled to require any compensation to the other party. The reward for the tabarru contract is from Allah, not from humans. However, the party doing the good deed may ask the counter-part to cover the costs incurred to perform the tabarru' contract. However, he must not take the slightest profit from the tabarru contract[28].

This tabarru' contract is a contract that is used for the benefit of the hereafter only, and this contract is not for commercial purposes. Explains further that if our goal is to profit, we use commercial contracts, namely tijarah contracts [29]. However, this does not mean that Cabarrus contracts cannot be used in commercial activities at all. The use of tabarru' contracts is vital in commercial transactions because this tabarru' contract can be used to bridge or facilitate tijarah contracts[30].

The results of the previous research described above and summarized in the table below show that both conceptually and actually, waqf is needed as an instrument in the economy to improve people's welfare [31]. The research conducted in this study is different from previous research in terms of research objects and research methods but has similarities to research conducted by using the Theory of Planned Behavior (TBP) [32].

This research is expected to contribute to efforts to maximize the collection of waqf through waqf institutions to improve the community's welfare, especially in Indonesia.

Table 1. Comparison of Previous Research with this Research

\begin{tabular}{|l|l|l|l|l|l|}
\hline No & $\begin{array}{l}\text { Researcher \& } \\
\text { Years }\end{array}$ & Research Title & $\begin{array}{l}\text { Research } \\
\text { Method }\end{array}$ & Research Result & $\begin{array}{l}\text { Comparison } \\
\text { with this } \\
\text { Research }\end{array}$ \\
\hline
\end{tabular}




\begin{tabular}{|c|c|c|c|c|c|}
\hline 1. & $\begin{array}{l}\text { (Mohammad, } \\
\text { 2018) }\end{array}$ & $\begin{array}{l}\text { Innovative Modes } \\
\text { of Financing the } \\
\text { Development of } \\
\text { Waqf Property }\end{array}$ & $\begin{array}{l}\text { Descriptive } \\
\text { method }\end{array}$ & $\begin{array}{l}\text { waqf development } \\
\text { projects apar from } \\
\text { the government } \\
\text { and semi } \\
\text { government } \\
\text { agencies can be } \\
\text { financed through } \\
\text { banks, developers, } \\
\text { and also by waqf } \\
\text { institutions using } \\
\text { self-financing }\end{array}$ & $\begin{array}{l}\text { This study } \\
\text { examines the } \\
\text { factors that } \\
\text { influence behavior } \\
\text { through the } \\
\text { intention of the } \\
\text { millennial } \\
\text { generation in } \\
\text { waqf. }\end{array}$ \\
\hline 2 & $\begin{array}{l}\text { (Ramli \& Jalil, } \\
\text { 2018) }\end{array}$ & $\begin{array}{l}\text { Corporate Waqf } \\
\text { Model and Its } \\
\text { Distinctive } \\
\text { Features: The } \\
\text { Future of Islamic } \\
\text { Philantrophy }\end{array}$ & $\begin{array}{l}\text { Study of } \\
\text { literature }\end{array}$ & $\begin{array}{l}\text { The advantages of } \\
\text { corporate waqf can } \\
\text { be observed from } \\
\text { several aspects: } \\
\text { significant funds } \\
\text { and assets, } \\
\text { professional } \\
\text { management team, } \\
\text { public trust in their } \\
\text { practices, and } \\
\text { government } \\
\text { recognition. } \\
\text { Corporate waqf } \\
\text { can be seen as the } \\
\text { most promising } \\
\text { model in waqf } \\
\text { development. }\end{array}$ & $\begin{array}{l}\text { The object of this } \\
\text { research is the } \\
\text { behavior of the } \\
\text { millennial } \\
\text { community in } \\
\text { waqf }\end{array}$ \\
\hline 3 & $\begin{array}{l}\text { (Huda, } \\
\text { Anggrraini, Rini, } \\
\text { Hudori, \& } \\
\text { Mardoni, 2020) }\end{array}$ & $\begin{array}{l}\text { Accountability as } \\
\text { a Waqf } \\
\text { Management } \\
\text { Solution }\end{array}$ & $\begin{array}{l}\text { Analytic } \\
\text { Network } \\
\text { Process (ANP) }\end{array}$ & $\begin{array}{l}\text { The priority of } \\
\text { solutions in each } \\
\text { aspect is divided } \\
\text { based on the } \\
\text { problem into each } \\
\text { of these aspects. }\end{array}$ & $\begin{array}{l}\text { This research } \\
\text { approach is } \\
\text { different as well as } \\
\text { the study area }\end{array}$ \\
\hline 4 & (Hasanah, 2020) & $\begin{array}{l}\text { The Role of } \\
\text { Waqf in } \\
\text { Realizing } \\
\text { Social Welfare: } \\
\text { A Case Study } \\
\text { of Waqf } \\
\text { Management in } \\
\text { South Jakarta }\end{array}$ & $\begin{array}{l}\text { Qualitative } \\
\text { Method }\end{array}$ & $\begin{array}{l}\text { Waqf management } \\
\text { in research } \\
\text { locations is only at } \\
\text { the stage of } \\
\text { leading to the } \\
\text { welfare of the } \\
\text { people and has not } \\
\text { been able to make } \\
\text { it happen in real } \\
\text { terms. }\end{array}$ & $\begin{array}{l}\text { This research } \\
\text { specifically talks } \\
\text { about the behavior } \\
\text { of the millennial } \\
\text { generation in } \\
\text { waqf and does not } \\
\text { relate it to welfare }\end{array}$ \\
\hline
\end{tabular}




\begin{tabular}{|l|l|l|l|l|l|}
\hline 5 & (Shalih, 2021) & $\begin{array}{l}\text { waqf in sharia } \\
\text { and its role in } \\
\text { community } \\
\text { development }\end{array}$ & $\begin{array}{l}\text { Qualitative } \\
\text { Method }\end{array}$ & $\begin{array}{l}\text { Waqf has a } \\
\text { significant role in } \\
\text { maintaining the } \\
\text { pillars of maqasid } \\
\text { shari'ah }\end{array}$ & $\begin{array}{l}\text { This research } \\
\text { does not examine } \\
\text { the maqasid } \\
\text { shari'ah }\end{array}$ \\
\hline
\end{tabular}

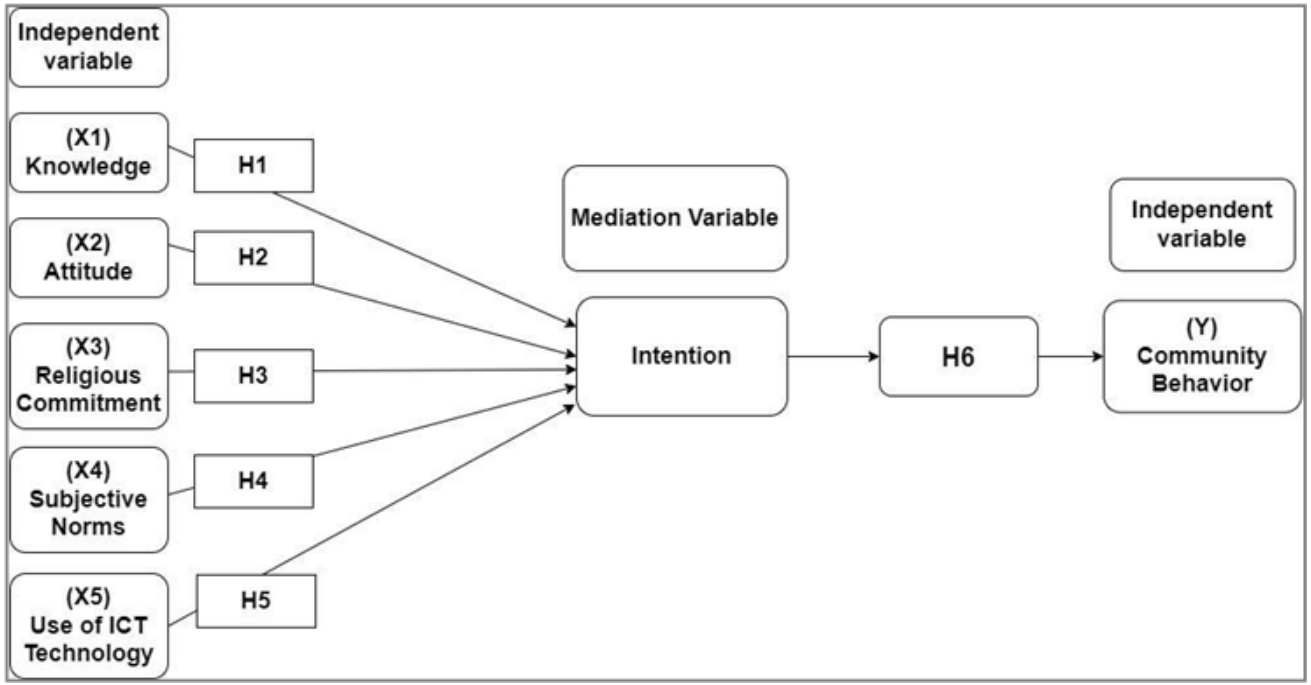

Figure 2. Conceptual Framework

The variables used in this study are Knowledge, Attitudes, Religious Commitment, Subjective Norms, Use of ICT Technology on Community Intentions, and Community Behavior in Millennial Society[33]. The exogenous variables are Knowledge, Attitude, Religious Commitment, Subjective Norms, Use of ICT Technology; endogenous variables are people's behavior.

\section{RESEARCH METHODOLOGY}

This research is research in the form of hypothesis testing, which aims to test hypotheses derived from available theories and previous research. This study will discuss the influence of knowledge, attitudes, religious commitment, subjective norms, and ICT technology on behavior through the intentions of millennials in Indonesia. The analysis used is Structural Equation Modeling (SEM)[34].

This research is also a quantitative descriptive study using primary data obtained through a survey using a questionnaire instrument distributed via google form to respondents. In addition, it is also equipped with secondary data sourced from publications in both print and electronic media[35]. This research is confirmatory research, which is a research activity carried out to test or prove the truth of pre-existing knowledge through the determination of hypotheses. This research is quantitative in short-term research because it will be carried out in under one year[36].

\subsection{Data Analysis Method}

The analytical method used in this research is using SEM (Structural Equation Modeling) using the AMOS program and with the help of SPSS software[37]. SEM model is a multivariate analysis technique that combines factor analysis and path analysis, allowing researchers to simultaneously test and estimate the relationship between multiple exogenous and endogenous multiple indicators. Factor analysis uses a maximum likelihood approach, allowing researchers to test the hypothesis that several factors can describe the intercorrelation between variables[38]. The hypothesis will be tested at an error rate of $5 \%$ and a significance level of $95 \%$.

\section{RESULTS AND DISCUSSION}

\subsection{Validity test}

Validity is carried out to measure the accuracy and accuracy of the measuring instrument in carrying out its function [39]. The validity test was carried out using the Pearson correlation technique on each question item in each construct to the total score of the construct. If each item has a positive correlation coefficient value with a significance value of test results less than 0.05 , then it can be stated that the question item is valid; 
otherwise, if each item has a negative coefficient value or the significance value of the test results is more significant than 0.05 then the question item is invalid[40].

Table 1. 30 Sample Questionnaire Validity Test Results

\begin{tabular}{|c|c|c|c|c|}
\hline Construct/Variable & $\begin{array}{l}\text { Statement } \\
\text { Items }\end{array}$ & Pearson $\mathrm{R}$ & P-Value & Decision \\
\hline \multirow[t]{3}{*}{ Knowledge } & A. 1 & $0,963 * *$ & 0,000 & Valid \\
\hline & A. 2 & $0,852 * *$ & 0,000 & Valid \\
\hline & A. 3 & $0,963 * *$ & 0,000 & Valid \\
\hline \multirow{3}{*}{ Attitude } & B. 1 & $0,653 * *$ & 0,000 & Valid \\
\hline & B. 2 & $0,958 * *$ & 0,000 & Valid \\
\hline & B. 3 & $0,653 * *$ & 0,000 & Valid \\
\hline \multirow[t]{4}{*}{$\begin{array}{l}\text { Religious } \\
\text { Commitment }\end{array}$} & C. 1 & $0,793 * *$ & 0,000 & Valid \\
\hline & C. 2 & $0,899 * *$ & 0,000 & Valid \\
\hline & C. 3 & $0,915 * *$ & 0,000 & Valid \\
\hline & C. 4 & $0,812 * *$ & 0,000 & Valid \\
\hline \multirow[t]{2}{*}{ Subjective Norms } & D. 1 & $0,983 * *$ & 0,000 & Valid \\
\hline & D. 2 & $0,983 * *$ & 0,000 & Valid \\
\hline $\begin{array}{l}\text { Use of ICT } \\
\text { Technology }\end{array}$ & E.1 & $0,894 * *$ & 0,000 & Valid \\
\hline
\end{tabular}




\begin{tabular}{|c|c|c|c|c|}
\hline & E. 2 & $0,815^{* *}$ & 0,000 & Valid \\
\hline \multirow{3}{*}{$\begin{array}{l}\text { Intention } \\
\text { Consumer }\end{array}$} & F.1 & $0,838^{* *}$ & 0,000 & Valid \\
\hline & F. 2 & $0,909^{* *}$ & 0,000 & Valid \\
\hline & F. 3 & $0,935^{* *}$ & 0,000 & Valid \\
\hline \multirow[t]{3}{*}{$\begin{array}{l}\text { Consumer } \\
\text { behavior }\end{array}$} & G.1 & $0,846^{* *}$ & 0,000 & Valid \\
\hline & G.2 & $0,669^{* *}$ & 0,000 & Valid \\
\hline & G.3 & $0,757^{* *}$ & 0,000 & Valid \\
\hline
\end{tabular}

The table above describes the results of the Validity Test, all measuring tools, namely Knowledge, Attitudes, Religious Commitment, Subjective Norms, Users of ICT Technology, Consumer Intentions, and Consumer Behavior. All measuring instruments meet the requirements, and it can be concluded that the measuring instruments in this study are valid.[41]

\subsection{Reliability Test}

The basis used in making decisions on reliability testing is if the value of Cronbach's Alpha is more significant than 0.70 , then the questionnaire or questionnaire can be called reliable.

Table 3. Reliability Test Results

\begin{tabular}{|l|l|l|}
\hline \multicolumn{1}{|c|}{ Variable } & \multicolumn{1}{|c|}{ Construct Reliability } & \multicolumn{1}{|c|}{ Conclusion } \\
\hline Knowledge & 0,916 & Reliable \\
\hline Attitude & 0,649 & Reliable \\
\hline Religious Commitment & 0,862 & Reliable \\
\hline Subjective Norms & 0,965 & Reliable \\
\hline
\end{tabular}




\begin{tabular}{|l|l|l|}
\hline Use of ICT . Technology & 0,625 & Reliable \\
\hline Intention Consumer & 0,862 & Reliable \\
\hline Consumer Behavior & 0,616 & Reliable \\
\hline
\end{tabular}

Based on the study results, it was found that the influence of knowledge on behavior through the intention of the Millennial generation in waqf is shown by the CR value of $0.704(p=0.481>0.05)$. Ho is accepted, and $\mathrm{Ha}$ is rejected, meaning that there is no influence between knowledge on behavior through the intention of the millennial generation. In waqf[42].

Based on descriptive analysis, the knowledge about waqf owned by the respondents is excellent; this shows that the Millennial generation already has good knowledge of waqf, even though good waqf knowledge does not guarantee interest in waqf. This follows research conducted[43], where the variable of waqf knowledge has no significant effect on interest in waqf. Based on the results of the study, it is known that the influence between attitudes towards consumer behavior is indicated by a CR value of $2.340(\mathrm{p}=0.019<0.05)$, then Ho is rejected, and $\mathrm{Ha}$ is accepted, meaning that there is a positive and significant influence between attitudes towards the intentions of the Millennial generation.

This result is by the theory (Hasyim \& Nurohman, 2021), which shows that attitude affects a person's intention to perform cash waqf[44].

\section{CONCLUSION}

Based on the results of this study, it was found that the knowledge variable did not affect the behavior of waqf through the intention of the millennial generation[45]. In contrast, the variables of attitude, commitment, subjective norms, and the use of ICT technology had a positive and significant effect on waqf behavior through the intention of the millennial generation[46]. This shows that although knowledge does not affect behavior, attitudes, commitment, subjective norms, and the use of ICT technology, the millennial generation has a positive and significant effect on waqf behavior.

Moreover, the results of the study can be concluded as follows:

1. Knowledge does not significantly affect the intention of the millennial generation in waqf in Jabodetabek.

2. Attitudes have a positive and significant influence on the intention of the millennial generation in waqf.

3. Religious commitment has a positive and significant influence on the intention of the millennial generation in waqf.

4. Subjective norms have a positive and significant influence on the intention of the millennial generation in waqf.

5. The use of ICT technology has a positive and significant influence on the intention of the millennial generation in waqf.

6. Consumer intentions have a positive and significant influence on the behavior of the millennial generation in waqf.

\subsection{Research Implication}

The findings in this study strengthen the concepts and theories related to measuring consumer behavior.

The novelties revealed from the results of this study in detail are as follows:

1. The Theory of Planned Behavior approach can measure consumer behavior by adding the variable of using ICT technology as a modification of the behavioral control variable component.

2. Good knowledge about waqf, supported by a good attitude and solid religious commitment as well as subjective norms or great intentions as well as the use of ICT technology in waqf, have an impact on people's intentions to waqf so that it will shape people's behavior, especially millennials to do waqf.

3. The factors that can influence people's behavior in waqf are attitudes, religious commitments, subjective norms, and the variable of using ICT technology through the 
community's intention to waqf. These results provide a new model in viewing people's behavior, especially the millennial generation[47].

\subsection{Research suggestions} follows:

The results of this study become the basis for the author to provide some suggestions, namely as

1. The institution responsible for the development of waqf and the wider community must optimally increase the knowledge and intentions of the community in waqf to increase the realization of waqf receipts. National socialization and campaigns are needed. Activities are held to increase public literacy about waqf held by institutions responsible for waqf development by inviting community elements from academics, practitioners, and the general public to stimulate them to know more interested vying for waqf.

2. Waqf institutions can develop ways of collecting waqf funds by making attractive and accessible applications for the community in the context of waqf. For that, we need professionals who know about the development of ICT technology.

\section{REFERENCES}

[1] H. S. Ryu, "What makes users willing or hesitant to use Fintech?: the moderating effect of user type," Ind. Manag. Data Syst., vol. 118, no. 3, pp. 541-569, 2018, doi: 10.1108/IMDS- 07-2017-0325/FULL/HTML.

[2] A. F. Utami, : Strategi, P. Wakaf..., A. Suman, and A. Manzilati, "Strategi Pengembangan Wakaf Produktif untuk Kesejahteraan Umat," Islam. J. Ekon. Islam, vol. 10, no. 2, Dec. 2019, doi: 10.32678/IJEI.V10I2.125.

[3] I. A. Kurniawan, D. Yusman, and I. O. Aprilia, "Utilization of Blockchain Technology Revolution in Electronic ID Card Data Integrity," APTISI Trans. Manag., vol. 5, no. 2, pp. 137-142, Apr. 2021, doi: 10.33050/ATM.V5I2.1530.

[4] J. D. Tan, J. T. Purba, and A. E. Widjaya, "Financial Technology as an Innovation Strategy for Digital Payment Services in the Millenial Generation,” pp. 364-373, Jan. 2019, doi: 10.2991/AGC-18.2019.58.

[5] U. Islam, N. Imam, and B. Padang, "JAMINAN SOSIAL MELALUI VOUCHER NASIONAL WAKAF," Al-Masraf J. Lemb. Keuang. dan Perbank., vol. 3, no. 1, pp. 93-105, Jun. 2018, doi: 10.15548/AL-MASRAF.V3I1.173.

[6] D. Bawah Bimbingan Arief Mufraini, "Pengaruh Motivasi, Persepsi, Sikap, Religiusitas, Pengetahuan Terhadap Keputusan Wakif Dalam Melakukan Wakaf (Studi Kasus: Kecamatan Serpong)," Mar. 2019, Accessed: Dec. 27, 2021. [Online]. Available: https://repository.uinjkt.ac.id/dspace/handle/123456789/45489.

[7] U. Rahardja, N. Lutfiani, A. Yolandari, J. Sistem Informasi, and S. Raharja, "Penerapan Viewboard Informatif Pada Asosiasi Perguruan Tinggi Swasta Indonesia Dalam Era Industri 4.0," Technomedia J., vol. 3, no. 2 Februari, pp. 224-234, Feb. 2019, doi: 10.33050/TMJ.V3I2.738.

[8] U. Rahardja, N. Lutfiani, ... A. R.-2020 8th I., and undefined 2020, "Determinants of Lecturer Performance to Enhance Accreditation in Higher Education," ieeexplore.ieee.org, Accessed: Jan. 05, 2022. [Online]. Available: https://ieexplore.ieee.org/abstract/document/9268871/.

[9] F. Hasyim, Y. Arif Nurohman, and I. Surakarta, “ADOPSI TEORI PERILAKU BERENCANA DALAM MENGANALISIS NIAT MELAKUKAN WAKAF TUNAI,” Among Makarti, vol. 14, no. 1, Jul. 2021, doi: 10.52353/AMA.V14I1.201.

[10] S. Sudaryono, Q. Aini, N. Lutfiani, F. Hanafi, and U. Rahardja, “Application of Blockchain Technology for iLearning Student Assessment,” IJCCS (Indonesian J. Comput. Cybern. Syst., vol. 14, no. 2, pp. 209-218, Apr. 2020, doi: 10.22146/IJCCS.53109.

[11] U. Rahardja, I. Handayani, N. Lutfiani, and F. P. Oganda, “An Interactive Content Media on Information System iLearning+,” IJCCS (Indonesian J. Comput. Cybern. Syst., vol. 14, no. 1, pp. 57-68, Jan. 2020, 
doi: 10.22146/IJCCS.51157.

[12] "Structural Equation Modeling with lavaan - Kamel Gana, Guillaume Broc - Google Books." https://books.google.co.id/books?hl=en\&lr=\&id=QMOCDwAAQBAJ\&oi=fnd\&pg=PP2\&dq=Structural+ Equation+Modeling + with+lavaan.\&ots=VlqJf-ex7I\&sig=9tc80UhjqzKpxrWKtCxI_S9377U\&redir_esc=y $\# \mathrm{v}=$ onepage \&q=Structural Equation Modeling with lavaan.\&f=false (accessed Dec. 27, 2021).

[13] U. Rahardja, N. Lutfiani, and H. L. Juniar, "Scientific Publication Management Transformation In Disruption Era," APTISI Trans. Manag., vol. 3, no. 2, pp. 109-118, Jul. 2019, doi: 10.33050/ATM.V3I2.1008.

[14] N. Subjektif, dan Partisipasi Terhadap Wakaf Tunai Muhammad Faisal Jurusan Akuntansi, and F. Ekonomi dan Bisnis, "Sikap, Norma Subjektif, Religiusitas, dan Partisipasi Terhadap Wakaf Tunai," Li Falah J. Stud. Ekon. dan Bisnis Islam, vol. 4, no. 2, pp. 235-250, Jan. 2020, doi: 10.31332/LIFALAH.V4I2.1548.

[15] "Laporan Hasil Survey Indeks Literasi Wakaf 2020 - Google Scholar." https://scholar.google.com/scholar?hl=en\&as_sdt= $0 \% 2 \mathrm{C} 5 \& \mathrm{q}=$ Laporan + Hasil + Survey + Indeks + Literasi $+\mathrm{w}$ akaf $+2020 \& b t n G=\# d=$ gs_cit\&u=\%2Fscholar\%3Fq\%3Dinfo\%3AfaJ3Ws_iRzwJ\%3Ascholar.google.com $\%$ 2F\%26output\%3Dcite\%26scirp\%3D0\%26hl\%3Den (accessed Dec. 27, 2021).

[16] I. Berakon et al., "E-PAYMENT: INOVASI LAYANAN PENGHIMPUNAN DAN REDISTRIBUSI WAKAF UANG BERBASIS ONLINE DALAM PERCEPATAN PEMBANGUNAN EKONOMI INDONESIA,” J. AL-QARDH, vol. 2, no. 1, pp. 26-41, Jun. 2017, doi: 10.23971/JAQ.V2I1.824.

[17] A. Ramadhan and S. Al-Harethi, "Perception from Students in Kolej University Insaniah," Ikon. J. Ekon. dan Bisnis Islam, vol. 4, no. 1, 2019, Accessed: Dec. 27, 2021. [Online]. Available: https://ejournal.radenintan.ac.id/index.php/ikonomika.

[18] hasanatul ahwal, "Wakaf Tunai Berbasis Crowdfunding: Persepsi Generasi Y dan Z," J. AL-IQTISHAD, vol. 17, no. 1, pp. 16-34, Jun. 2021, doi: 10.24014/JIQ.V17I1.12580.

[19] S. Sudaryono, U. Rahardja, and D. Apriani, "The CICES Journal Governance Performance Improvement on Quality Of Current Issues (Case Study of STMIK RAHARJA)," APTISI Trans. Manag., vol. 3, no. 1, pp. 57-64, Feb. 2019, doi: 10.33050/ATM.V3I1.578.

[20] R. Al Hakim, I. Mustika, W. Yuliani, and P. Studi Bimbingan dan Konseling, "VALIDITAS DAN RELIABILITAS ANGKET MOTIVASI BERPRESTASI," FOKUS (Kajian Bimbing. Konseling dalam Pendidikan), vol. 4, no. 4, pp. 263-268, Jul. 2021, Accessed: Dec. 27, 2021. [Online]. Available: https://www.journal.ikipsiliwangi.ac.id/index.php/fokus/article/view/7249.

[21] U. Rahardja, N. Lutfiani, and S. Amelia, "Creative Content Marketing In Scientific Publication Management In Industrial Era 4.0," APTISI Trans. Manag., vol. 3, no. 2, pp. 168-177, Aug. 2019, doi: 10.33050/ATM.V3I2.991.

[22] R. Hidayatur, "pengaruh strategi penggalangan wakaf tunai dan religiusitas terhadap minat masyarakat untuk berwakaf pada pengelolaan wakaf ranting muhammadiyah kertosari kabupaten ponorogo tahun 2018." IAIN Ponorogo, 2018.

[23] W. Ramadayanti and K. Kosasih, "The Influence of Financial Performance on People's Business Credit in Banking Companies for the Period 2010-2019," APTISI Trans. Manag., vol. 5, no. 1, pp. 73-78, Jan. 2021, doi: 10.33050/ATM.V5I1.1435.

[24] N. Fahmi and Z. Fuadi, "Wakaf sebagai Instrumen Ekonomi Pembangunan Islam,” Econ. J. Ekon. Islam, vol. 9, no. 1, pp. 151-177, Jul. 2018, doi: 10.21580/ECONOMICA.2018.9.1.2711.

[25] K. M. Ali, M. Yuliani, S. Mulatsih, and Z. Abdullah, "Aspek-Aspek Prioritas Manajemen Wakaf di Indonesia,” AL-FALAH J. Islam. Econ., vol. 3, no. 1, pp. 1-28, Jul. 2018, doi: 10.29240/JIE.V3I1.345.

[26] E. Erlina and D. Hermawan, "Marketing Mix on Customer Loyalty at Coffee Shop in Bandung," APTISI 
Trans. Manag., vol. 5, no. 1, pp. 89-96, Jan. 2021, doi: 10.33050/ATM.V5I1.1488.

[27] U. Rahardja, Q. Aini, F. Budiarty, M. Yusup, and A. Alwiyah, "Socio-economic impact of Blockchain utilization on Digital Certificates," APTISI Trans. Manag., vol. 5, no. 2, pp. 106- 111, Mar. 2021, doi: 10.33050/ATM.V5I2.1508.

[28] N. dan Khurun et al., "POTENSI WAKAF TUNAI DALAM MENINGKATKAN USAHA KECIL MENENGAH (UKM): STUDI PADA BADAN WAKAF UANG TUNAI (BWUT) MAJELIS ULAMA INDONESIA (MUI) YOGYAKARTA,” AL-BAYAN Islam. LAW Econ., vol. 2, no. 2, pp. 1-16, Dec. 2021, doi: 10.35964/AB.V2I2.26.

[29] M. L. Hakim and S. Asiyah, "Perkembangan Wakaf Asuransi Syariah di Indonesia Pasca Terbitnya Fatwa DSN-MUI No. 106 Tahun 2016," Islam. Rev. J. Ris. dan Kaji. Keislam., vol. 9, no. 2, pp. 191-208, Oct. 2020, doi: 10.35878/ISLAMICREVIEW.V9I2.223.

[30] S. Purwaningsih1 and D. D. Susilowati, "PERAN WAKAF DALAM MENINGKATKAN PEMBERDAYAAN EKONOMI UMAT,” J. Ekon. Bisnis, dan Akunt., vol. 22, no. 2, pp. 191- 203, Jun. 2020, doi: 10.32424/JEBA.V22I2.1595.

[31] S. Purnama, A. Sukmasari, and R. Bhandari, "The Role of Religiosity as a Mediating Variable in the Relationship between Online Transactions and Customer Satisfaction and Loyalty in Islamic Banking," APTISI Trans. Manag., vol. 5, no. 2, pp. 143-151, Mar. 2021, doi: 10.33050/ATM.V5I2.1532.

[32] M. B. Ardy, N. Nilawati, and Z. F. Umari, "Analisis SWOT terhadap Wakaf Tunai di Badan Wakaf Indonesia Provinsi Sumatera Selatan,” J. Intelekt. Keislaman, Sos. dan Sains, vol. 10, no. 1, pp. 189-200, Jun. 2021, doi: 10.19109/INTELEKTUALITA.V10I1.8668.

[33] P. Edastama, "The Importance of Maslahah Orientation in Sharia Institutions," APTISI Trans. Manag., vol. 5, no. 2, pp. 180-190, May 2021, doi: 10.33050/ATM.V5I2.1595.

[34] K. Fikriyah and W. Y. Alam, "Perkembangan Keuangan Syariah dalam Realitas Politik di Indonesia," J. Ilm. Ekon. Islam, vol. 7, no. 3, pp. 1594-1601, Nov. 2021, doi: 10.29040/JIEI.V7I3.2687.

[35] R. Z. Syahrir and Eri Prasetyo Wibowo, "Classification of Leaves Based on the Shape of Leaves Using Convolutional Neural Network Methods," IAIC Trans. Sustain. Digit. Innov., vol. 3, no. 1, pp. 1-7, Oct. 2021, doi: 10.34306/ITSDI.V3I1.491.

[36] Jerry Heikal, Vitto Rialialie, D. Rivelino, and Ign Agus Supriyono, "Hybrid Model Of Structural Equation Modeling Pls And Rfm (Recency, Frequency And Monetary) Model To Improve Bank Average Balance," Aptisi Trans. Technopreneursh., vol. 4, no. 1, pp. 1-8, Dec. 2021, doi: 10.34306/ATT.V4I1.221.

[37] Setiawansyah, H. Sulistiani, A. Yuliani, and F. Hamidy, "Perancangan Sistem Informasi Akuntansi Upah Lembur Karyawan Menggunakan Extreme Programming," Technomedia J., vol. 6, no. 1, Jun. 2021, doi: 10.33050/TMJ.V6I1.1421.

[38] N. Nurcahyani, “Tinjaun Undang-Undang Nomor 41 Tahun 2004 tentang Wakaf terhadap tugas Nazir dalam Mengelola Wakaf Produktif di Masjid Baitul Amin Desa Bader Kecamatan Dolopo Kabupaten Madiun," Jun. 2021.

[39] B. Witjaksono, T. Mariyanti, M. E. Nasution, N. Huda, and N. Rini, "Factors which influence the intention of community in cash waqaf in sharia banking with theory planned behaviour (TPB) modification approach," jibfnet.com, vol. 7, no. 2, pp. 50-58, 2019, doi: 10.15640/jibf.v7n2a5.

[40] U. Rahardja, Q. Aini, F. Budiarty, M. Yusup, and A. Alwiyah, "Socio-economic impact of Blockchain utilization on Digital certificates," Aptisi Trans. Manag., vol. 5, no. 2, pp. 106- 111, Mar. 2021, doi: 10.33050/ATM.V5I2.1508.

[41] M. Nurchaerani, Haryati, and F. Nursyamsi, "Upaya Meningkatkan Minat Belajar Di Masa Pandemi 
Melalui Pelatihan Bahasa Inggris Secara Daring,” ADI Pengabdi. Kpd. Masy., vol. 2, no. 1, pp. 1-7, Oct. 2021, doi: 10.34306/ADIMAS.V2I1.451.

[42] T. Ayuninggati, E. P. Harahap, Mulyati, and R. Junior, "Supply Chain Management, Certificate Management at the Transportation Layer Security in Charge of Security," Blockchain Front. Technol., vol. 1, no. 01, pp. 1-12, Jun. 2021, Accessed: Dec. 27, 2021. [Online]. Available: https://journal.pandawan.id/b-front/article/view/3.

[43] A. Bagus Setiawan, W. Rachmawati, A. Taufiq Arrahman, N. Natasyah, and F. N. S. Fadil, "Aplikasi Monitoring Stok Barang Berbasis Web Pada PT. Intermetal Indo Mekanika," ADI Bisnis Digit. Interdisiplin J., vol. 2, no. 2, pp. 1-6, Sep. 2021, doi: 10.34306/ABDI.V2I2.254.

[44] F. Ilmu Pengetahuan Islam Berbasis Teknologi Dalam Perspektif Epistemologi Zaharuddin et al., "Filsafat Ilmu Pengetahuan Islam Berbasis Teknologi Dalam Perspektif Epistemologi," Alph. J. Wawasan Agama Risal. Islam. Teknol. dan Sos., vol. 1, no. 1, pp. 1-15, Oct. 2021, Accessed: Dec. 27, 2021. [Online]. Available: https://journal.pandawan.id/al-waarits/article/view/23.

[45] A. Pambudi, R. Widayanti, and P. Edastama, "Trust and Acceptance of E-Banking Technology Effect of Mediation on Customer Relationship Management Performance," ADI J. Recent Innov., vol. 3, no. 1, pp. 87-96, Sep. 2021, doi: 10.34306/AJRI.V3I1.538.

[46] T. Nurhaeni, N. Lutfiani, A. Singh, W. Febriani, and M. Hardini, "The Value of Technological Developments Based on An Islamic Perspective," Int. J. Cyber IT Serv. Manag., vol. 1, no. 1 SE-Articles, pp. 1-13, Apr. 2021, [Online]. Available: https://iiastjournal.org/ijcitsm/index.php/IJCITSM/article/view/4.

[47] P. Hendriyati, F. Agustin, U. Rahardja, and T. Ramadhan, "Management Information Systems on Integrated Student and Lecturer Data," APTISI Trans. Manag., vol. 6, no. 1, pp. 1-9, Jul. 2022, doi: 10.33050/ATM.V6I1.1527. 